\title{
The Serum Glucose Response to Glucagon Suppression with Somatostatin, Insulin or Antiglucagon Serum in Depancreatized Rats
}

\author{
J.C. Dunbar, M. F. Walsh, and P.P. Foà
}

Department of Physiology, Wayne State University, School of Medicine and Department of Research, Sinai Hospital of Detroit, Detroit, Michigan, USA

Summary. Total immunoreactive glucagon (IRG) and immunoreactive glucagon of $\mathrm{A}$ cell origin $\left(I_{R} G_{a}\right)$ were measured in the serum of normal, sham-operated and depancreatized rats, after the administration of three glucagon antagonists: insulin (5-200 $\mathrm{mU} / \mathrm{rat} / \mathrm{h})$, somatostatin (SRIF; $100 \mu \mathrm{g} / \mathrm{kg} / \mathrm{h}$ ) and antiglucagon serum (AGS, enough to bind three times the calculated total amount of circulating IRG). Since no differences were noted between the responses of normal and sham-operated animals, the values were pooled and used as controls. Pancreatectomy caused a significant increase in serum glucose, $\mathrm{IRG}_{\mathrm{a}}$ and total IRG and a significant decrease in serum insulin. AGS and SRIF significantly decreased serum glucose in control, but not in depancreatized rats, even though SRIF caused a significant decrease of IRG $\mathrm{I}_{\mathrm{a}}$ in all animals. SRIF significantly decreased plasma insulin in control rats, but did not modify total IRG secretion in either group. In control rats the minimum effective hypoglycaemic dose of insulin $(5 \mathrm{mU} / \mathrm{rat} / \mathrm{h})$ may have decreased serum IRG $_{\mathrm{a}}$, but not total IRG. At higher doses $(20 \mathrm{mU} / \mathrm{rat} / \mathrm{h})$ insulin stimulated glucagon secretion. In depancreatized animals, higher doses of insulin $(200 \mathrm{mU} / \mathrm{rat} / \mathrm{h})$ were needed to lower serum glucose. On the other hand, a dose of $100 \mu \mathrm{U} / \mathrm{rat} / \mathrm{h}$ was sufficient to lower the serum IRG. We conclude that although hyperglucagonaemia may contribute to the hyperglycaemia of the untreated depancreatized rats, the excessive secretion of glucagon is secondary to insulin insufficiency and that, at least in this animal model, the hypoglycaemic action of insulin is only minimally dependent upon its ability to suppress glucagon secretion.

Key words: Glucagon, somatostatin, insulin, antiglucagon serum, glucagon suppression, serum glucose.
High serum levels of immunoreactive glucagon (IRG) associated with hyperglycaemia have been observed not only in patients with glucagon producing tumours $[17,22]$ but also in animals and in patients with a variety of debilitating conditions $[1,26]$ and with diabetes mellitus $[4,13,21,30]$. In particular, persistent or elevated levels of circulating IRG have been found in depancreatized dogs [19, $20,33]$ and in some [23, 32], but not all, [2] depancreatized patients. The purpose of this study was to evaluate the role of extrapancreatic IRG in the pathogenesis of hyperglycaemia in the rat. We used depancreatized animals in whom the only known sources of IRG are the gastrointestinal tract, salivary glands and possibly the kidneys $[6,15,16,25]$. Hyperglycaemic, ketotic rats, with high serum immunoreactive glucagon levels, were treated with somatostatin (SRIF), antiglucagon serum (AGS) and insulin, three inhibitors of glucagon secretion or glucagon action $[3,5,10,35]$.

\section{Materials and Methods}

\section{Definitions}

Since most substances with glucagon-like immunoreactivity found in blood and tissues are poorly characterized, we have reserved the name "glucagon" for the chemically defined pancreatic hormone and have called all other materials "immunoreactive glucagon" or IRG, with qualifications. Thus, total IRG is the fraction measured with a "non-specific" antiserum that reacts with glucagon and with extracts of intestinal mucosa and $I_{R G_{a}}$ is the material secreted by the A cells found in the pancreas and elsewhere and measured with an antiserum "specific" for pancreatic glucagon. Appropriate words, e.g. pancreatic, intestinal, or salivary indicate the probable sources of IRG. 
Normal, depancreatized and sham-operated male Sprague-Dawley rats (300-350 grams) were used. One-stage pancreatectomy and sham surgery, consisting of laparatomy and manipulation of pancreas and intestines, were performed under pentobarbital (Nembutal, Abbott Laboratories, North Chicago, Illinois) anaesthesia $(30 \mathrm{mg} / \mathrm{kg}, \mathrm{IP}) . \mathrm{Im}-$ mediately after surgery, the animals received $0.5 \mathrm{ml}$ of an antibiotic (Distrycillin A.S., E. R. Squibb and Sons, Princeton, New Jersey) and $10 \mathrm{ml}$ of $\mathrm{NaCl}$ $(0.154 \mathrm{~mol} / \mathrm{l})$ solution subcutaneously. Thereafter, the rats were kept in individual metabolic cages with water and food ad libitum. Urinary glucose and ketones were estimated with Labstix (Ames Company, Elkhart, Indiana). Glycosuria $(2-3+)$ and ketonuria $(1-2+)$ appeared on the first postoperative day and became progressively more severe thereafter. On the second postoperative day, the animals began to eat and to lose weight. Four to 5 days after surgery, after a 24 hour fast, the rats appeared well groomed and in fair health although they had suffered an average weight loss of about $15 \%$. At this time, they were anaesthetized again with sodium pentobarbital and both external jugular veins were cannulated. One cannula was used for the removal of blood, the other for the introduction of experimental solutions. A rabbit antiglucagon serum (AGS 28), which had a binding capacity of $20 \mathrm{ng}$ of pancreatic glucagon per $\mathrm{ml}$ and did not distinguish between the latter and glucagon-like materials extracted from intestinal mucosa [9], was injected intravenously in a single dose sufficient to bind at least 3 times the total amount of circulating IRG. This amount, up to $3.0 \mathrm{ml}$ per rat, was calculated from the serum levels of total IRG measured with a similar antiserum (AGS 10), assuming a blood volume equal to $10 \%$ of body weight. In two depancreatized rats we injected $6.0 \mathrm{ml}$ of AGS. At the end of the experiment the animal's serum could still bind glucagon in vitro, indicating that the injected dose of AGS was in excess of the amount needed. Control rats received an equal volume of normal rabbit serum. SRIF (cyclic somatostatin, $100 \mu \mathrm{g} / \mathrm{kg} / \mathrm{h}$, Ayerst Laboratories, New York, New York), insulin $(5-200 \mathrm{mU} / \mathrm{rat} / \mathrm{h})$ and $\mathrm{NaCl}(0.154 \mathrm{~mol} / \mathrm{l})$ solution were infused over a $2 \mathrm{~h}$ period with the aid of a pump (Harvard Apparatus Company, Millis, Massachusetts). One $\mathrm{ml}$ of blood was collected before the beginning of the infusion; other samples were $0.25 \mathrm{ml}$, except the last $(120 \mathrm{~min})$ sample which was $2.0 \mathrm{ml}$. The blood was placed immediately into chilled test tubes and spun in a refrigerated centrifuge. The serum was transferred to a tube containing aprotinin (Trasylol, FBA Pharmaceuticals Inc., New York, New York), an inhibitor of proteolysis (1000
Kallikrein inactivator units per $\mathrm{ml}$ ) and stored at $-20^{\circ} \mathrm{C}$. Glucose was measured enzymatically (GOD Perid method, Boehringer Mannheim Corp., New York, New York) and glucagon by means of a double-antibody radioimmunoassay previously described [28], using ${ }^{125}$ I-labelled porcine glucagon (New England Nuclear, Boston, Massachusetts) and porcine standards (prepared from lot \#258-D30138-4, gift of Dr.Mary Root, Lilly Research Laboratories, Indianapolis, Indiana). Two antiglucagon sera were used: AGS 10, which reacts with pancreatic glucagon and with intestinal glucagon-like materials and measures total immunoreactive glucagon and AGS 18, which reacts minimally with extracts of intestinal mucosa and measures IRG secreted by the A cells of the pancreas and of other organs (IRG $\mathrm{I}_{\mathrm{a}}$ ). The characteristics of these antisera have been described previously [9]. Insulin was measured with the method of Hales and Randle [12] using porcine insulin standards and ${ }^{125}$ I-labelled porcine insulin. The latter was prepared from lot \#PJ 5682 (gift of Dr. Mary Root, Lilly Research Laboratories, Indianapolis, Indiana) according to Greenwood and Hunter [11]. We have determined previously [18] that our anti-insulin serum binds less rat insulin than porcine insulin, though at values lower than $20 \mu \mathrm{U} / \mathrm{ml}$ the difference becomes insignificant. In any case all IRG and IRI values should be considered porcine hormone equivalents. The results are expressed as means \pm SEM. Their statistical significance was calculated using Student's $t$ test.

\section{Results}

No significant differences were noted between the results obtained in normal and in sham-operated rats; therefore, the two groups of values were combined and used as control data. Removal of the pancreas resulted in a significant increase in the serum levels of glucose, total IRG and IRG $\mathrm{I}_{\mathrm{a}}$ and in a significant decrease in serum IRI, which, however, did not disappear completely (Table 1 ).

The injection of AGS, but not normal rabbit serum, into normal rats caused a significant decrease in serum glucose that reached a nadir in about $30 \mathrm{~min}$, persisted for about $1 \mathrm{~h}$, thereafter returning to the preinfusion and, in some cases, higher values. Neither serum significantly modified the serum glucose concentration of depancreatized rats (Fig. 1). This was true also in the two depancreatized rats which received twice as much AGS $(6 \mathrm{ml})$ as the others (data not recorded).

Following the infusion of SRIF we noted a sig- 
Table 1. Serum glucose, insulin, A cell glucagon $\left(\mathrm{IRG}_{\mathrm{a}}\right)$ and total glucagon (total $\left.I R G\right)$ in normal and depancreatized rats. Ave. \pm SEM Number of rats in parentheses

\begin{tabular}{|c|c|c|c|c|}
\hline & \multirow[t]{2}{*}{ Glucose $\mathrm{mg} / 100 \mathrm{ml}$} & \multirow[t]{2}{*}{$\begin{array}{l}\text { Insulin } \mu \mathrm{u} / \mathrm{ml} \\
\text { (porcine equivalents) }\end{array}$} & \multicolumn{2}{|c|}{$\begin{array}{l}\text { Glucagon } \mathrm{pg} / \mathrm{ml} \\
\text { (porcine equivalents) }\end{array}$} \\
\hline & & & $\mathrm{IRG}_{\mathrm{a}}$ & Total IRG \\
\hline Normal & $\begin{array}{l}92 \pm 3 \\
(11)\end{array}$ & $\begin{array}{l}41 \pm 6 \\
(10)\end{array}$ & $\begin{array}{l}62 \pm 9 \\
(15)\end{array}$ & $\begin{array}{l}446 \pm 66 \\
(11)\end{array}$ \\
\hline Depancreatized & $\begin{array}{l}453 \pm 52^{b} \\
(19)\end{array}$ & $\begin{array}{l}13 \pm 2^{\mathrm{a}} \\
(18)\end{array}$ & $\begin{array}{l}152 \pm 40^{\mathrm{a}} \\
(17)\end{array}$ & $\begin{array}{l}1079 \pm 136^{\mathrm{a}} \\
(15)\end{array}$ \\
\hline
\end{tabular}

${ }^{\mathrm{a}} \mathrm{p}<0.01 ;{ }^{\mathrm{b}} \mathrm{p}<0.001$

Table 2. Serum IRG I $_{a}$ total IRG and IRI before and 120 minutes following somatostatin infusion $(100 \mu \mathrm{g} / \mathrm{kg} / \mathrm{hr})$ in normal and depancreatized rats. Ave. \pm SEM. Number of rats in parentheses

\begin{tabular}{|c|c|c|c|c|c|c|}
\hline & \multicolumn{2}{|l|}{$\mathrm{IRG}_{\mathrm{a}}$} & \multicolumn{2}{|l|}{ Total IRG } & \multicolumn{2}{|l|}{ IRI } \\
\hline & 0 & 120 & 0 & 120 & 0 & 120 \\
\hline Normal & $\begin{array}{l}71 \pm 11 \\
(11)\end{array}$ & $\begin{array}{l}33 \pm 7 \\
(5)\end{array}$ & $\begin{array}{l}334 \pm 24 \\
(7)\end{array}$ & $\begin{array}{l}328 \pm 78 \\
(7)\end{array}$ & $\begin{array}{l}36 \pm 5 \\
(11)\end{array}$ & $\begin{array}{l}20 \pm 3^{\mathrm{a}} \\
(5)\end{array}$ \\
\hline Depancreatized & $\begin{array}{l}152 \pm 40 \\
(17)\end{array}$ & $\begin{array}{l}18 \pm 4^{a} \\
(6)\end{array}$ & $\begin{array}{l}1239 \pm 108 \\
(6)\end{array}$ & $\begin{array}{l}980 \pm 123 \\
(6)\end{array}$ & - & - \\
\hline
\end{tabular}

${ }^{a}=p<0.05$ vs 0 time

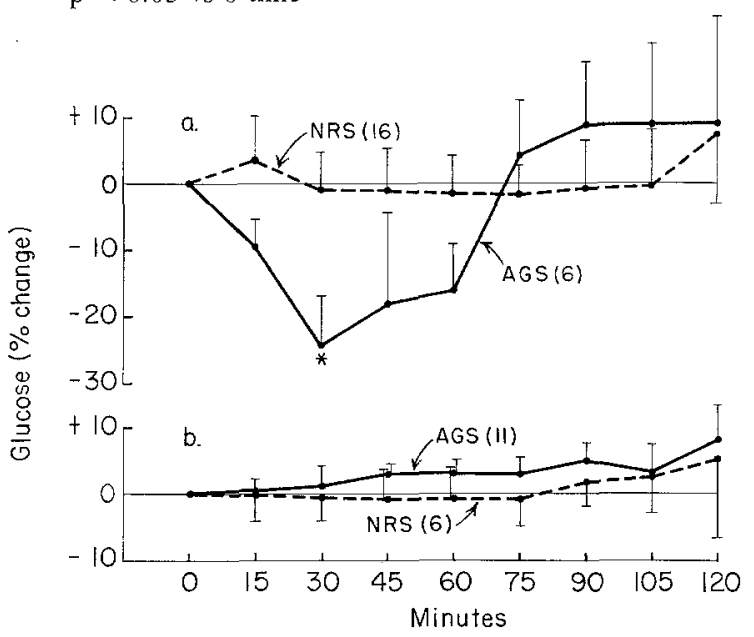

Fig. 1. Effect of antiglucagon serum (AGS) and of normal rabbit serum (NRS) on serum glucose in normal (a) and depancreatized (b) rats. Ave. initial serum glucose $(\mathrm{mg} / 100 \mathrm{ml})$ in normal rats: AGS-treated 95; NRS-treated 104; in depancreatized rats: AGStreated, 448; NRS-treated $460{ }^{*}=\mathrm{p}<0.05$

nificant decrease in the level of serum IRI in normal rats and in the level of serum IRG $_{\mathrm{a}}$ in normal and depancreatized rats. This reduction in $I_{R G}$ accounted for the effect of SRIF on total IRG, but it was not statistically significant, due to the large standard error (Table 2). Serum glucose decreased significantly in normal, but not in depancreatized rats (Fig. 2).

The effect of insulin on the serum glucose con-

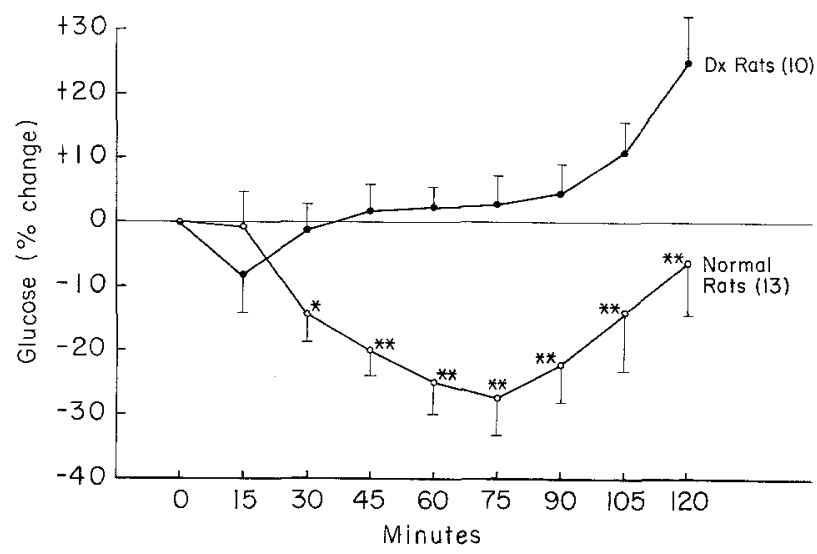

Fig. 2. Effect of somatostatin infusion $(100 \mu \mathrm{g} / \mathrm{kg} / \mathrm{h})$ on serum glucose in normal and depancreatized (DX) rats. Ave. initial serum glucose values $(\mathrm{mg} / 100 \mathrm{ml})$ : normal rats, 106; depancreatized rats $381 . *=p<0.05 ; * *=p<0.01$

centration of normal rats varied with the dose (Fig. $3)$. The smallest dose $(5 \mathrm{mU} / \mathrm{rat} / \mathrm{h})$ caused a slight, non-significant decrease in total IRG and $\mathrm{IRG}_{\mathrm{a}}$ in normal animals. However, when insulin was infused in larger amounts, the resulting hypoglycaemia was accompanied by a significant stimulation of $\mathrm{IRG}_{\mathrm{a}}$ and consequently of total IRG (Table 3). Insulin caused a significant decrease in $I_{R G}$ and total IRG of depancreatized rats only in doses of $100 \mathrm{mU} /$ 


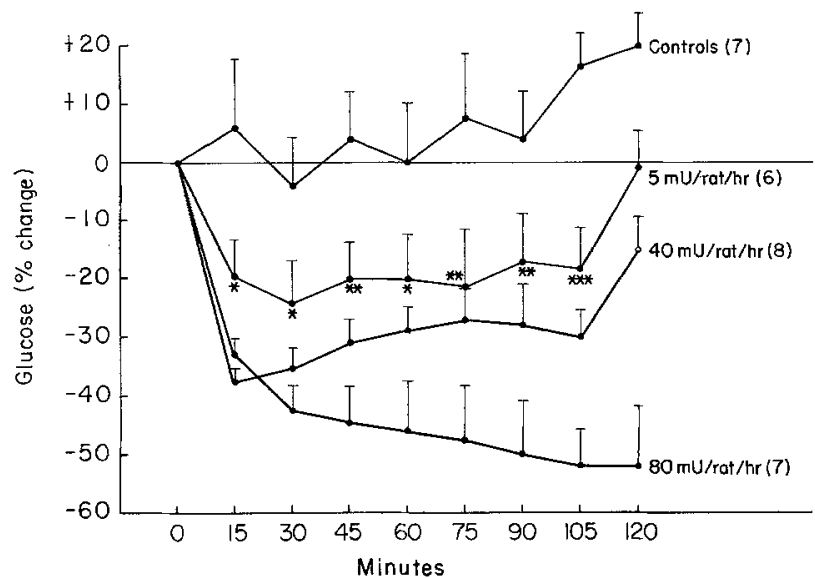

Fig. 3. Effect of insulin infusion on serum glucose in normal rats. Ave. initial serum glucose, $104 \mathrm{mg} / 100 \mathrm{ml}$ * $=p<0.05$; $* *=p<0.01 ; * * *=p<0.001$

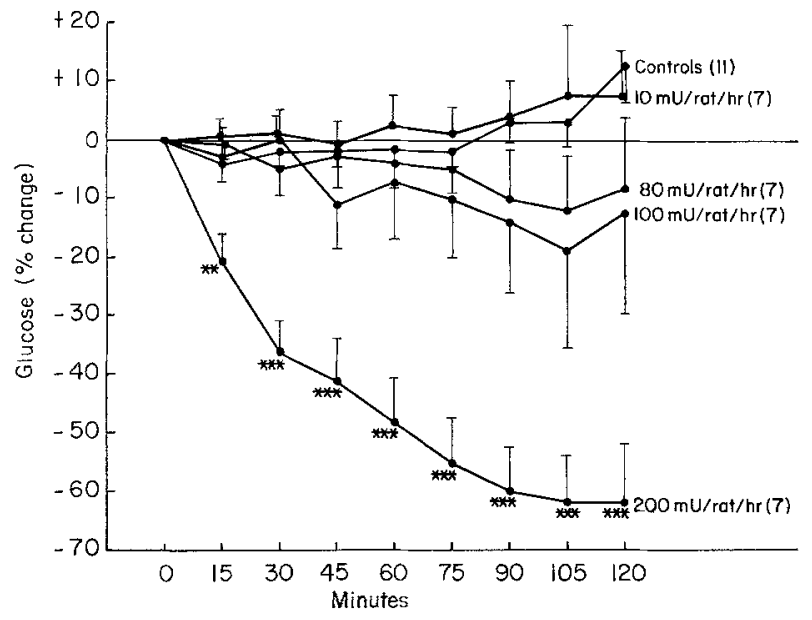

Fig. 4. Effect of insulin infusion on serum glucose in depancreatized rats. Ave. initial serum glucose, $518 \mathrm{mg} / 100 \mathrm{ml}$. $* *=\mathrm{p}<0.01 ; * * *=\mathrm{p}<0.001$

Table 3. Serum IRG $I_{a}$ and total IRG in normal and depancreatized rats 120 minutes following insulin infusion. Ave \pm SEM. Number of rats in parentheses

\begin{tabular}{lccc}
\hline & $\mathrm{mU} / \mathrm{rat} / \mathrm{h}$ & $\mathrm{IRG}_{\mathrm{a}}$ & Total IRG \\
\hline Normal & 0 & $75 \pm 24(4)$ & $446 \pm 66(11)$ \\
& 5 & $46 \pm 19(4)$ & $343 \pm 58(3)$ \\
Depancreatized & 0 & $186 \pm 55(7)$ & $1007 \pm 133(15)$ \\
& 80 & $166 \pm 30(4)$ & $893 \pm 228(6)$ \\
& 100 & $49 \pm 16(9)^{\mathrm{a}}$ & $476 \pm 91(13)^{\mathrm{b}}$ \\
& 200 & $61 \pm 16(7)^{\mathrm{a}}$ & $540 \pm 80(6)^{\mathrm{b}}$ \\
\hline
\end{tabular}

${ }^{a} \mathrm{p}<0.05$ vs 0 control; ${ }^{\mathrm{b}} \mathrm{p}<0.01$ vs 0 control $\mathrm{rat} / \mathrm{h}$ or more (Table 3). On the other hand, a significant lowering of serum glucose required a dose of at least $200 \mathrm{mU} / \mathrm{rat} / \mathrm{h}$ (Fig. 4).

\section{Discussion}

The untreated depancreatized animal is a convenient experimental model for the study of extrapancreatic glucagon since, when given no insulin, it rapidly develops not only hyperglycaemia and ketosis, but also high serum levels of IRG $\mathrm{a}_{\mathrm{a}}$ and total IRG. In our depancreatized rats (we could not use dogs for obvious reasons of AGS economy) circulating glucagon rose significantly, even though measurable amounts of endogenous IRI were still present. Four explanations may be offered for these findings: decreased rates of hormone degradation or excretion; release of previously stored hormones; hormone secretion by extrapancreatic tissues; and failure to remove the entire pancreas. We know of no evidence suggesting that pancreatectomy alters the normal processes of insulin or glucagon disposal, or the release of tissue bound hormones. On the other hand, there is evidence that the pancreas is not the sole source of insulin and of glucagon since IRI, $I_{R G}$ and total IRG have been found in the salivary glands $[6,14,15,25]$, in the kidneys $[6,16]$, and in the gastrointestinal tract $[8,27,29,31]$.

Finally, even though we may have failed to remove small portions of the pancreas in some rats, all of them developed marked hyperglycaemia, glycosuria and ketosis and, in any case, subtotal pancreatectomy and the resulting hyperglycaemia could explain the presence of residual IRI, but not the rise in pancreatic IRG. In any case, IRI and IRG do not disappear entirely from the blood even after total evisceration $[6,24]$, a procedure which makes total pancreatectomy a virtual certainty. We suggest that, by removing the pancreas, we may have removed the inhibitory influence of insulin and pancreatic glucagon on the release of IRG from any residual pancreatic A cells or from extrapancreatic sources [7].

The binding of IRG by AGS resulted in a significant lowering of the blood glucose level in fasted normal rats. This effect lasted 30 to $60 \mathrm{~min}$, or about as long as the hyperglycaemic effect of a glucagon injection [34], suggesting that a biologically significant portion of the circulating IRG had indeed been bound and subsequently released by the antibody. On the other hand AGS had no effect in depancreatized rats whose serum glucose continued to increase during the $2 \mathrm{~h}$ period of observation. The reason for this different response is not 
readily apparent: perhaps, in the normal rat, a decrease in $\mathrm{IRG}_{\mathrm{a}}$ allows insulin to exert its full effect, while in the depancreatized, insulin-deficient animal, this is not possible. A crucial role of insulin and a relatively minor role of glucagon are suggested also by the observation that the suppression of $I R G_{a}$ by SRIF failed to decrease the level of serum glucose in depancreatized rats, although it had a hypoglycaemic effect in normal animals.

Progressively larger doses of insulin caused a progressively larger decrease in the serum glucose of normal rats, but only the lowest doses caused a slight non-significant decrease in serum $\mathrm{IRG}_{\mathrm{a}}$ and total IRG. Larger doses caused greater hypoglycaemia associated with an increased level of both IRG fractions. Thus, although insulin may have inhibited IRG secretion in normal rats, this effect was masked by the stimulatory effect of hypoglycaemia. On the other hand, insulin significantly decreased the serum levels of IRG $G_{\mathrm{a}}$ and total IRG in depancreatized rats, even when the dose was insufficient to cause a significant decrease in their serum glucose. Thus, the suppression of IRG $\mathrm{I}_{\mathrm{a}}$ by SRIF or of total IRG (including IRG I $_{\mathrm{a}}$ ) by insulin was not necessarily associated with a reduction in serum glucose, indicating that glucagon did not play an essential role in the pathogenesis of hyperglycaemia in depancreatized rats. On the other hand, while in the normal animals insulin-induced hypoglycaemia was associated with a rise in IRG $_{a}$, in the depancreatized ones it was associated with a decrease in $I R G_{a}$. These findings suggest that in the insulin-deprived rat insulin is capable of suppressing glucagon secretion, at least as long as the serum glucose does not reach hypoglycaemic levels. We believe that our data are consistent with the conclusions that, in the rat, insulin is required for the proper function of the pancreatic and extrapancreatic glucagon-secreting cells; that although hyperglucagonaemia may contribute to the hyperglycaemia of the depancreatized animal, the excessive secretion of glucagon is secondary to insulin insufficiency and that, at least in this species, the hypoglycaemic action of insulin does not depend primarily upon its ability to suppress glucagon secretion.

Acknowledgements. Aided by Grant No. AM06034 from the National Institute of Arthritis, Metabolism and Digestive Diseases and by a grant from the American Diabetes Association, Michigan Affiliate.

\section{References}

1. Aguilar-Parada, E., Eisentraut, A.M., Unger, R. H.: Effects of starvation on plasma pancreatic glucagon in normal man. Diabetes 18, 717-723 (1969)
2. Bloom, S.R., Barnes, A.J., Bryant, M.G., Alberti, K. G. M. M.: Plasma glucagon in diabetes resulting from total pancreatectomy. Metabolism 25, 1481-1482 (1976)

3. Buchanan, K.D.: Insulin and glucose control of pancreatic glucagon release. Diabetologia 7, 473 (1971)

4. Buchanan, K.D., McCarroll, A. M.: Abnormalities of glucagon metabolism in untreated diabetes mellitus. Lancet 1972 II, $1394-1395$

5. Christensen, S. E., Hansen, A.P., Iversen, J., Lundbaek, K., Ørskov, H., Seyer-Hansen, K.: Somatostatin as a tool in studies of basal carbohydrate and lipid metabolism in man: modifications of glucagon and insulin release. Scand. J. Clin. Lab. Invest. 34, 321-325 (1974)

6. Dunbar, J. C., Silverman, H., Kirman, E., Foà, P. P.: Role of the submaxillary gland and of the kidney in the hyperglucagonemia of eviscerated rats. In: P.P. Foà, J.S. Bajaj, N.L. Foà (eds.): Glucagon. Its role in physiology and clinical medicine. (In press 1977)

7. Dunbar, J.C., Walsh, M.F., Foà, P.P.: Secretion of immunoreactive insulin and glucagon in hamsters bearing a transplantable insuloma. Diabète et Metab. (Paris) 2, 165-169 (1976)

8. Foà, P.P., Berger, S., Santamaria, L., Smith, J. A., Weinstein, H.R.: Extraction of the hyperglycemic factor (HGF) of the pancreas with liquid ammonia. Science 117, 82-84 (1953)

9. Foà, P.P., Matsuyama, T., Foà, N. L.: Radioimmunoassay of glucagon. In: G.E. Abraham (ed.): Handbook of radioimmunoassay, pp. 299-318. New York: Marcel Dekker 1977

10. Gerich, J.E., Lovinger, R., Grodsky, G. M.: Inhibition by somatostatin of glucagon and insulin release from the perfused rat pancreas in response to arginine, isoproterenol, and theophylline: evidence for a preferential effect on glucagon secretion. Endocrinology 96, 749-754 (1975)

11. Greenwood, F.C., Hunter, W.M.: The preparation of ${ }^{131} \mathrm{I}-$ labelled human growth hormone of high specific radioactivity. Biochem. J. 89, 114-123 (1963)

12. Hales, C. N., Randle, P. J.: Immunoassay of insulin with insulin antibody precipitate. Biochem. J. 88, 137-146 (1963)

13. Laube, H., Fussgänger, R.D., Maier, V., Pfeiffer, E.F.: Hyperglucagonaemia of the isolated perfused pancreas of diabetic mice (db/db). Diabetologia 9, 400-402 (1973)

14. Lawrence, A. M., Kirsteins, L., Mitton, J.: Parotid gland insulin: an extrapancreatic source of insulin in rats. Diabetes $\mathbf{2 5}$, Suppl. 1, 328 (1976)

15. Lawrence, A. M., Tan, S., Hojvat, S., Kirsteins, L.: Salivary gland hyperglycemic factor: An extrapancreatic source of glucagon-like material. Science 195, 70-72 (1977)

16. Lefèbvre, P. J., Luyckx, A.S.: Effect of acute kidney exclusion by ligation of renal arteries on peripheral plasma glucagon levels and pancreatic glucagon production in the anesthetized dog. Metabolism 24, 1169-1176 (1975)

17. Leichter, S.B., Pagliara, A.S., Grieder, M.H., Pohl, S., Kipnis, D.M.: Uncontrolled diabetes mellitus and hyperglucagonemia associated with an islet cell carcinoma. Am. J. Med. 58, 285-293 (1975)

18. Loreti, L., Dunbar, J. C., Chen, S., Foà, P.P.: The autoregulation of insulin secretion in the isolated pancreatic islet of lean (obob) and obese-hyperglycemic (obob) mice. Diabetologia 10, 309-315 (1974)

19. Mashiter, K., Harding, P.E., Chou, M., Mashiter, R.D., Stout, J., Diamond, D., Field, J.B.: Persistent pancreatic glucagon but not insulin response to arginine in pancreatectomized dogs. Endocrinology 96, 678-693 (1975)

20. Matsuyama, T., Foà, P. P.: Plasma glucose, insulin, pancreatic and enteroglucagon levels in normal and depancreatized dogs. Proc. Soc. Exp. Biol. Med. 147, 97-102 (1974)

21. Matsuyama, T., Hoffman, W.H., Dunbar, J.C., Foà, N.L., Foà, P.P.: Glucose, insulin, pancreatic glucagon and 
glucagon-like immunoreactive materials in the plasma of normal and diabetic children. Effect of the initial insulin treatment. Horm. Metab. Res. 7, 452-456 (1975)

22. McGavran, M.H., Unger, R.H., Recant, L., Polk, H.C., Kilo, C., Levin, M.E.: A glucagon-secreting alpha-cell carcinoma of the pancreas. N. Engl. J. Med. 274, 1408-1413 (1966)

23. Palmer, J.P., Werner, P.L., Benson, J.W., Ensinck, J. W.: Immunoreactive glucagon responses to arginine in three pancreatectomized humans. Metabolism 25, 1483-1485 (1976)

24. Penhos, J. C., Ezequiel, M., Lepp, A., Ramey, E. R.: Plasma immunoreactive insulin (IRI) and immunoreactive glucagon (IRG) after evisceration with and without a functional liver. Diabetes 24, 637-640 (1975)

25. Printseva, O. I., Shubnikova, E. A.: Identification of insulinlike substance in submaxillary salivary glands of mice by the method of fluorescent antibodies. Dokl. Akad. Nauk, S. S. S. R. 233, 484 (1977)

26. Rocha, D. M., Santeusanio, F., Faloona, G. R., Unger, R. H.: Abnormal pancreatic alpha-cell function in bacterial infections. N. Engl. J. Med. 288, 700-730 (1973)

27. Sasaki, H.B., Rubalcava, B., Baetens, D., Blàzquez, E., Srikant, C. B., Orci, L., Unger, R. H.: Identification of glucagon in the gastrointestinal tract. J. Clin. Invest. 56, 135-145 (1975)

28. Shima, K., Foà, P. P.: A double antibody assay for glucagon. Clin. Chim. Acta 22, 511-520 (1968)

29. Sutherland, E.W., Cori, C.F., Haynes, R., Olsen, N.S.: Purification of the hyperglycemic glycogenolytic factor from insulin and from gastric mucosa. J. Biol. Chem. 180, 825-837 (1949)
30. Unger, R.H., Aguilar-Parada, E., Müller, W. A., Eisentraut, A.M.: Studies of pancreatic alpha-cell function in normal and diabetic subjects. J. Clin. Invest. 49, 837-848 (1970)

31. Valverde, I., Villaneuva, M.L., Lozano, I., Marco, J.: Presence of glucagon immunoreactivity in the globulin fraction of human plasma ("Big Plasma Glucagon"). J. Clin. Endocrinol. Metab. 39, 1090-1098 (1974)

32. Villanueva, M.L., Hedo, J.A., Marco, J.: Plasma glucagon immunoreactivity in a totally pancreatectomized patient. Diabetologia 12, 613-616 (1976)

33. Vranic, M., Pek, S., Kawamori, R.: Increased glucagon immunoreactivity in plasma of totally depancreatized dogs. Diabetes 23, 905-912 (1974)

34. Whitty, A.J., Shima, K., Trubow, M., Foà, P.P.: Effect of glucagon and insulin on serum free fatty acids in normal and depancreatized dogs. Proc. Soc. Exp. Biol. Med. 130, 55-61 (1969)

35. Yen, S.S.C., Siler, T.M., DeVane, G.W.: Effect of somatosatin in patients with acromegaly: suppression of growth hormone, prolactin, insulin and glucagon levels. N. Engl. J. Med. 290, 935-938 (1974)

Received: March 28, 1977, and in revised form: July 20, 1977

Dr. Joseph C. Dunbar Department of Research Sinai Hospital of Detroit 6767 West Outer Drive Detroit, MI 48235

USA 